EISSN: 2706-7955 ISSN: 2077-4605

DOI: 10.36632/mejar/2021.10.1.26

Journal homepage: www.curresweb.com

Pages: 400-412

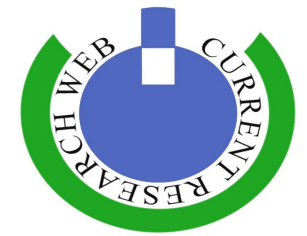

\title{
Impact of Bio and Inorganic Potassium and Nitrogen Fertilization on Yield and Its Attributes of Promising Sugarcane Genotypes
}

\author{
El-Taib A.B.A. ${ }^{1}$, A. M. Attia ${ }^{2}$ and Sakina R. Abazid ${ }^{3}$ \\ ${ }^{1}$ Department of Agronomy, Faculty of Agriculture and Natural Resources, Aswan University, Egypt. \\ ${ }^{2}$ Soils, Water and Environment Research Institute, Agriculture Research Center, Giza, Egypt. \\ ${ }^{3}$ Sugar Crops Research Institute, Agriculture Research Center, Giza, Egypt.
}

Received: 08 January $2021 \quad$ Accepted: 20 March $2021 \quad$ Published: 25 March 2021

\begin{abstract}
A field experiment was conducted at Kom-Ombo Agricultural Research Station, (latitude of $24^{\circ} 28^{\prime}$ $\mathrm{N}$ and longitude of $32^{\circ} 57^{\prime} \mathrm{E}$ at an elevation $108 \mathrm{~m}$ above sea level), Aswan Governorate, Egypt during $2018 / 2019$ and 2019/2020 seasons to study the effect of bio and inorganic potassium and nitrogen fertilization on yield and its attributes of some sugar cane genotypes. The study included 48 treatments, which were the combinations of four sugar cane genotypes (G.2006-6 , G.2003-49, C.57-14 and G.T.54-9 as a check), three potassium rates (48 kg inorganic $\mathrm{K}_{2} \mathrm{O}, 40 \mathrm{~kg}$ inorganic $\mathrm{K}_{2} \mathrm{O}+400$ gram bio $\mathrm{K}$ and $34 \mathrm{~kg}$ inorganic $\mathrm{K}_{2} \mathrm{O}+800$ gram bio $\mathrm{K} /$ fed.) and four nitrogen rates (210 kg inorganic $\mathrm{N}, 190 \mathrm{~kg}$ inorganic $\mathrm{N}+300$ gram bio $\mathrm{N}, 170 \mathrm{~kg}$ inorganic $\mathrm{N}+600$ gram bio $\mathrm{N}$ and $150 \mathrm{~kg}$ inorganic $\mathrm{N}+900$ gram bio $\mathrm{N}$ fed. A split-split plot design with three replications was used. The results showed that the four sugar cane genotypes significantly differed in the all studied traits. The results indicated that studied bio and inorganic potassium fertilization rates affected significantly in millble cane number, height, and cane yield in both seasons, as well as millable cane diameter weight and nitrogen $\%$ in leaves in first season only. Results showed that studied, bio and inorganic nitrogen fertilization levels affected significantly in millable cane number, height, weight, and cane yield in both seasons. While, millable cane diameter in first season only. Under conditions of the present work, supplying sugar cane G.2006-6 genotypes with $100 \%$ of the recommended inorganic k-rate ( $48 \mathrm{~kg} \mathrm{~K}_{2} \mathrm{O} / \mathrm{fed}$.) integrated with $100 \%$ of the recommended inorganic $\mathrm{N}$-rate $(210 \mathrm{~kg} / \mathrm{fed}$.) and $90 \%$ of the recommended inorganic K-rate $(40 \mathrm{~kg})+400 \mathrm{~g}$ bio- $\mathrm{K} /$ fed. integrated with $70 \%$ of recommended inorganic N-rate $(150 \mathrm{~kg})+$ $900 \mathrm{~g}$ bio- $\mathrm{N} /$ fad resulted in the highest cane yield/fed. in $1^{\text {st }}$ and $2^{\text {nd }}$ seasons respectively.
\end{abstract}

Keywords: Sugar cane genotypes, Mineral and bio-K \&N fertilization, cane yield.

\section{Introduction}

The adoption of agriculture on one commercial variety is the main problem facing cultivation in Egypt. So, it requires the possibility of using new varieties of alternative to the only commercial variety G.T 54-9. Recently, Sugar Crops Research Institute produced some promising varieties of sugar cane among them G.2006-6, G.2003-49 and C.57-14. Many studies were carried out to select among the produced varieties in yield and its components, as well as juice quality parameters among them (Osman et al. 2010; Galal et al. 2015; Mehareb and Abazied 2016; Ahmed et al. 2018; Ahmed, et al. 2020; and Gadallah and Mehareb 2020).

Sugar cane is one of the crops that need many amounts of nutrients especially potassium and nitrogen. So, it is better to use other substances which give the nutrients for growing the plants and decrease the environmental pollution. Bio-fertilizers are part of the substances that decrease the environmental pollution and have economic advantages.

Potassium plays a pivotal role in sugar cane production. It is an enzyme activator in plant metabolisms such as photosynthesis, and translocation of sugars. Many investigators cleared the role of

Corresponding Author: El-Taib A.B.A., Department of Agronomy, Faculty of Agriculture and Natural Resources, Aswan University, Egypt. E-mail: awadattiaa@yahoo.com 
bio, inorganic potassium for sugar cane (Taha, et al. 2003; Ahmed, et al. 2008; Behnam et al. 2015; Hemeid et al. 2017; Watanabe, et. al., 2019 and Sasy, and Abu-Ellail 2021).

Nitrogen is vital for plant metabolic processes and plays an important role in tillering and stalk elongation. In addition, $\mathrm{N}$ deficiency results in reduction of leaf area and thus, causes photosynthesis reduction which in turn leads to suppress in yield and quality. Many investigators pointed out the importance of the role of bio, inorganic nitrogen in respect to its influence on yield and its components characteristics of sugar cane (Buragohain, 2000; Rao et al. 2000; Hari and Srinivasan, 2005; Ahmed and El-Shafai, 2007; Ashraf et al. 2008; Yousif et al. 2015; El-Geddawy, and Makhlouf, 2016; Abazied and El-Bakry, 2018; and Sasy, and Abu-Ellail, 2021).

The objective of this study was to assess the effect of bio, inorganic nitrogen and Potassium fertilization on yield, its attributes of promising sugar cane varieties and decrease the environmental pollution by chemical fertilizers.

\section{Materials and Methods}

A field experiment was conducted at Kom-Ombo Agricultural Research Station, (latitude of $24^{\circ}$ $28^{\prime}$ North and longitude of $32^{\circ} 57^{\prime}$ East at an elevation $108 \mathrm{~m}$ above sea level), Aswan Governorate, Egypt during 2018/2019 and 2019/2020 seasons to study the effect of bio, inorganic potassium and nitrogen fertilization rates on yield and its attributes of some sugar cane genotypes. The study included 48 treatments, which were the combinations of four sugar cane genotypes (G.2006-6, G.2003-49, C. 57-14 and G.T.54-9 as a check), three bio, inorganic potassium rates i. e $\mathrm{K} 1: 48 \mathrm{~kg}$ inorganic $\mathrm{K}_{2} \mathrm{O}, \mathrm{K} 2: 40 \mathrm{~kg}$ inorganic $\mathrm{K}_{2} \mathrm{O}+400$ gram bio fertilizer and $\mathrm{K} 3: 34 \mathrm{~kg}$ inorganic $\mathrm{K}_{2} \mathrm{O}+800$ gram bio fertilizer/fed.) and four bio and inorganic nitrogen rates i. e N1: $210 \mathrm{~kg}$ inorganic nitrogen , N2: $190 \mathrm{~kg}$ inorganic nitrogen + 300 gram bio fertilizer, N3: $170 \mathrm{~kg}$ inorganic nitrogen +600 gram bio fertilizer and N4: $150 \mathrm{~kg}$ inorganic nitrogen +900 gram bio fertilizer/ fed

Randomized complete block design, in split-split plot design with three replications was used. The genotypes were arranged in the main plots, while, bio and inorganic potassium levels were randomly distributed in sub-plots and the sub-sub plots were assigned for bio and inorganic nitrogen rates. Plot area was $42 \mathrm{~m}^{2}$ (including six ridges of seven meters in length and one meter apart). Sugar cane varieties were planted in the $1^{\text {st }}$ week of March (plant cane). Harvesting date was done at age of twelve months for plant and ratoon cane crops. Some physical and chemical properties of the experimental site according to Black (1965) and Ryan et al., (1996) are shown in Table (1).

Table 1: Some physical and chemical properties of the experiment soil before sowing.

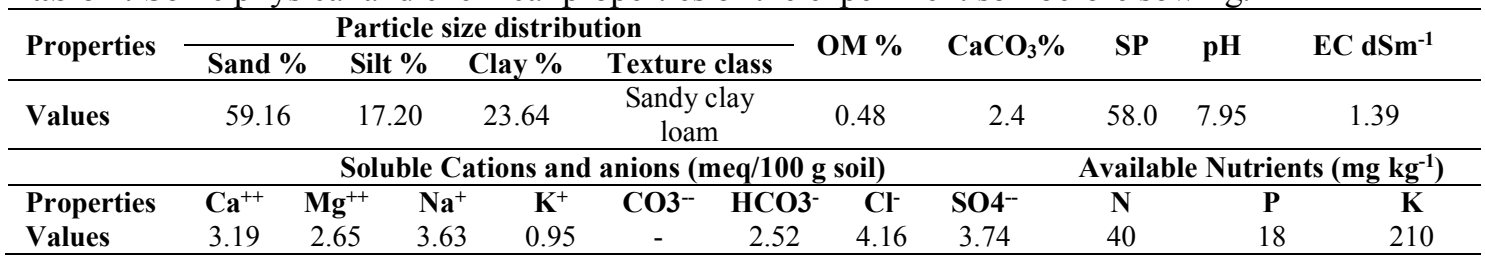

The bio fertilizers used contain nitrogen fixed bacteria's: Azotobacter and Azospirillum brasilense, and potassium dissolving bacteria: Bacillus circulans. At the concentration $9^{10}$ colony forming unit/g for each was used. The bio-fertilizers provided by the Unit of Bio-fertilizers productionMicrobiology Research Department, Soils, Water and Environment Research Institute, Agricultural Research Center, Giza. Egypt.

Bio- potassium or/and nitrogen fertilizers were mixed with sand and manually thrown on cane cuttings in furrows at planting the plant cane crop, and irrigation was immediately practiced. In the $1^{\text {st }}$ ratoon crop, the two bio-fertilizers were applied before the $1^{\text {st }}$ dose of inorganic nitrogen fertilizer.

Inorganic $\mathrm{N}$ fertilizer was added in the form of Urea $(46.5 \% \mathrm{~N})$ in three doses. In the plant cane, the $1^{\text {st }}$ nitrogen dose was applied after two months from planting. In the $1^{\text {st }}$ ratoon, the $1^{\text {st }}$ nitrogen dose was added after one month from harvesting. Meanwhile, second dose was followed after one month later as well as the third dose. 
Inorganic Potassium fertilizer was applied in the form of potassium sulphate, $48 \% \mathrm{~K}_{2} \mathrm{O}$ with the $2^{\text {nd }}$ $\mathrm{N}$-dose, for the plant cane and $1^{\text {st }}$ ratoon cane. All plots received the usual agronomic practices as recommended for sugar cane.

\subsection{Recorded data}

Number of millable canes/fad was recorded, at harvesting. A sample of twenty millable canes for each of the studied treatments was taken to determine the following characters:

Millable cane height $(\mathrm{cm})$, millable cane diameter $(\mathrm{cm})$, millable cane weight $(\mathrm{kg})$, and cane yield (ton/fad) was calculated based on plot area.

After 120 days from planting date a random sample of plant top (Top visible dewlap (T.V.D.) leaves was collected to determine nitrogen and potassium contents according to the method described by A.O.A.C. (1995). Nitrogen was determined by Kjeldahl method and potassium was determined using flame photometer. Samples of soil were taken from each treatment at harvesting to determine availability of the nitrogen, phosphorus and potassium.

The collected data were statistically analyzed according to the method described by Snedecor and Cochran (1981). Treatment means were compared using LSD at 5\% level of difference as outlined by Steel and Torrie (1980).

\section{Results and Discussion}

\subsection{Number of millable cane / fed.}

The data presented in Table 2 show that the differences among tested sugar cane genotypes in the number of millable cane per faddan were significant in both seasons. G.2006-6 genotype recorded the highest mean value of millable cane number / fed. (44850/ fed. in plant cane while, the corresponding mean value in first ratoon crops (44500/fed.) was recorded by G.2003-49 genotype. This result may be due to the genetic difference among genotypes in tillering ability and capacity of producing more survive and harvestable stalks. Significant differences among cane varieties in this trait were also reported by Osman, et al (2010); Galal et al. (2015); and Ahmed, et al. (2020), they reported that significant differences among the tested varieties in the millable cane number $/ \mathrm{m}^{2}$.

It is clearly from the results in same Table that the effect of potassium fertilizer on the number of millable cane /fad was significant in plant and $1^{\text {st }}$ ratoon crops. The $3^{\text {rd }}$ level of potassium $\left(34 \mathrm{Kg} \mathrm{K}_{2} \mathrm{O}+800 \mathrm{~g}\right.$ Bio fertilizer /fed.) gave the highest value of millable cane number /fed. in plant cane, while the highest value for ratoon crop was obtained by applying $40 \mathrm{Kg} \mathrm{K}_{2} \mathrm{O}+800+400 \mathrm{~g}$ Bio fertilizer/fed. This increase may be due to the role of potassium fertilizer in physiological processes in plants. These results are harmony with those obtained by Taha et al. (2003), Behnam et al. (2015) and Sasy, and Abu-Ellail (2021), they found that potassium affected the number of millable cane/fed.

Here too, number of millable cane/fed. was significantly influenced by the applied $\mathrm{N}$ levels in both seasons. N1 treatment (210 kg inorganic nitrogen) gave the highest millable cane number $/ \mathrm{fed}$. in $1^{\text {st }}$ season, while, $\mathrm{N} 3$ rates $(170 \mathrm{~kg}$ inorganic $\mathrm{N}+600 \mathrm{~g}$ bio fertilizer $\mathrm{N})$ gave the highest value in this respect in the $2^{\text {nd }}$ season. This result might be due to increasing absorption of $\mathrm{N}$ by sugar cane and decreasing $\mathrm{NO}_{3}$ leaching, which may be reflected in better $\mathrm{N}$ use efficiency as result of colonizing sugar cane rhizosphere with $\mathrm{N}$ fixing bio agent. These findings are in a good line with those reported by Ahmed and El-Shafai (2007); Geddawy and Makhlouf (2016) and Sasy, and Abu-Ellail (2021) found that application of mineral, Bio-N fertilizers significantly and positively attained a continuous increments in number of millable cane/fed.

Also, the illustrated data in same Table focus that all the first and second order interactions involved in this respect had a significant influence on the millable cane number /fed. in both seasons. Thus, the highest number of millable cane/fed. (49200) was obtained from G.T.54-9 genotype plants which were fertilized by $48 \mathrm{~kg} \mathrm{~K} /$ fed. and 170 mineral $\mathrm{N}+600$ gm bio-N $($ G.T.54-9 $\times \mathrm{K} 1 \times \mathrm{N} 3)$ or by the same genotype fertilized by $34 \mathrm{Kg}$ mineral $\mathrm{K}_{2} \mathrm{O}+800 \mathrm{~g}$ bio $-\mathrm{K} / \mathrm{Fed}$ and $190 \mathrm{Kg}$ mineral N. $+300 \mathrm{~g}$ bio- N/Fed. (G.T.54-9 $\times \mathrm{K} 3 \times \mathrm{N} 2$ ) or by G. 2006-6 genotype which was fertilized by $48 \mathrm{~kg} \mathrm{~K}_{2} \mathrm{O}$ and $210 \mathrm{~kg} \mathrm{~N} / \mathrm{fed}$. (G.2006-6 $\times \mathrm{K} 1 \times \mathrm{N} 1)$ while the corresponding mean value in the second season (45900) was recorded from G.T.54-9 genotype plants which were fertilized by $48 \mathrm{~kg} \mathrm{~K} /$ fed. and 190 mineral $\mathrm{N}+300$ gm bio fertilizer $\mathrm{N}($ G.T.54-9 $\times \mathrm{K} 1 \times \mathrm{N} 2)$ or by G.2003-49 genotype which was fertilized by $40 \mathrm{~kg}$ inorganic potassium + $400 \mathrm{~g}$ bio fertilizer $\mathrm{K}$ and 170 mineral $\mathrm{N}+600 \mathrm{~g}$ bio-N $(\mathrm{G} .2003-49 \times \mathrm{K} 2 \times \mathrm{N} 3)$. 
Table 2: Millable cane number/fed. as affected by genotypes, bio, inorganic potassium and nitrogen fertilization rates in the plant cane and $1^{\text {st }}$ ratoon crop.

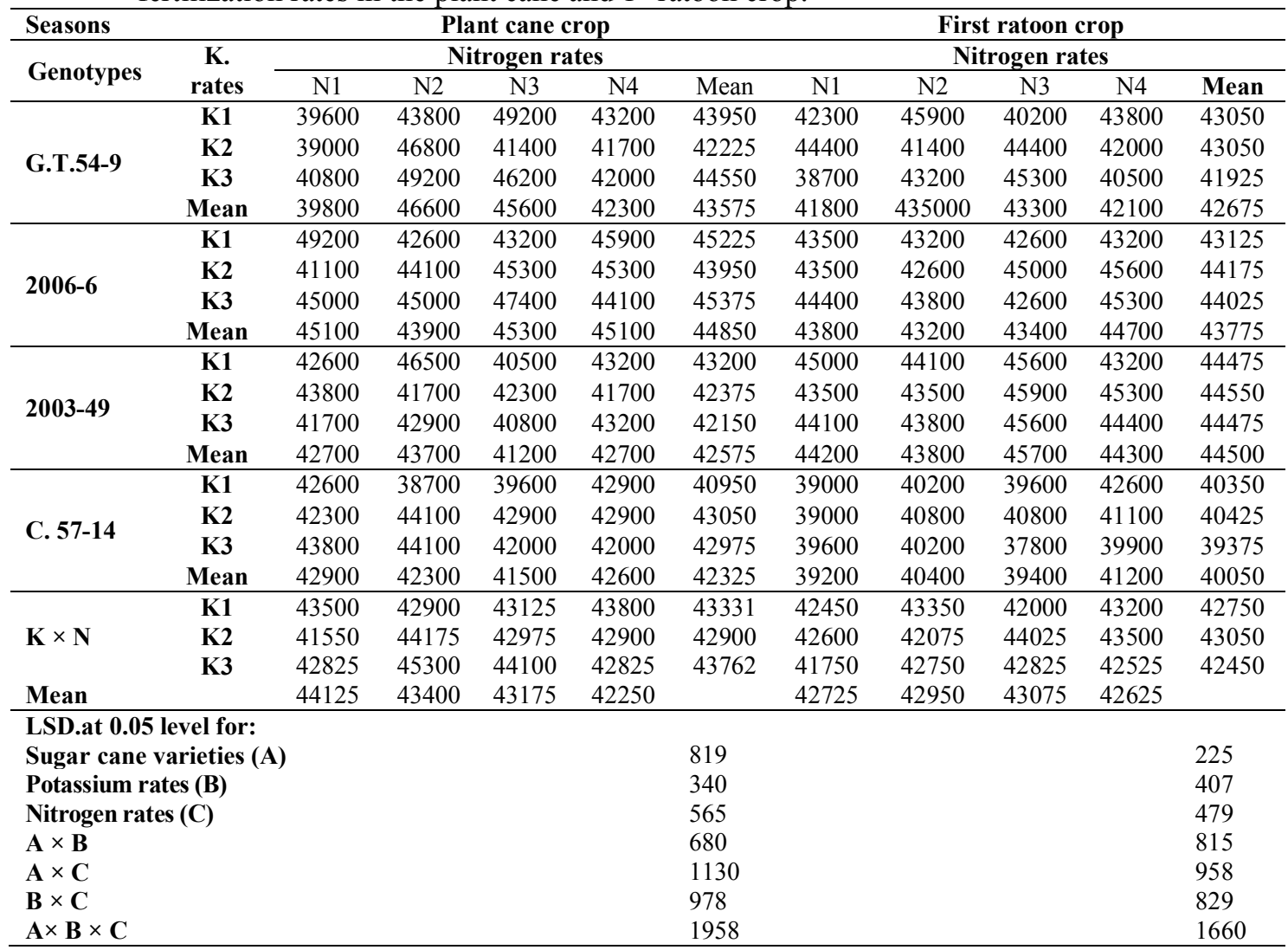

\subsection{Millable cane height $(\mathrm{cm})$}

Data in Table (3) reveal that studied sugar cane genotypes differed significantly in millable cane height. Sugar cane G.T.54-9 genotype had the tallest millable cane in both seasons, while G. 2003-49 and G. 2006-6 genotypes had the shortest millable cane in plant and $1^{\text {st }}$ ratoon crops, respectively. This result could be attributed to the genetic differences among tested genotypes in their ability of the formation of internodes and /or determination of their height. Similar results were reported by Galal et al. (2015); Ahmed et al. (2018) and Gadallah and Mehareb (2020) found that cane varieties differed markedly in stalk height.

Furthermore, the results denote that millable cane height trait was affected significantly by studied potassium fertilizer levels (Table 3). Adding K2 and K1 potassium fertilization rates to sugar cane plants produced the tallest stalks in the plant and first ratoon crops, respectively. This result may be due to the role of potassium in physiological processes in sugar cane plants. Similar results were obtained by Taha et al. (2003); Ahmed, et al. (2008), Hemeid (2017) and Watanabe, et al. (2019) reported that K had significantly affected in cane height.

Moreover, millable cane height was significantly affected by nitrogen doses in the two crops. N4 nitrogen treatment $(150 \mathrm{Kg}$ mineral nitrogen $+900 \mathrm{~g}$ bio fertilizer $\mathrm{N} /$ fed.) produced the tallest millable cane length in both seasons (Table 3). These results might be due to the role of nitrogen in the division of stalk cells. These results are agreement with those obtained by Ashraf et al. (2008); Yousif et al. (2015) and Abazied and El-Bakry (2018) found that nitrogen application doses had significant influence on millable cane height in both seasons.

Here too, the millable cane height was significantly affected by the first and second order interactions in both seasons (Table 3). Thus, the highest millable cane height ( $287 \mathrm{~cm}$ in the first season) was obtained from G.T.54-9 genotype which was fertilized with $40 \mathrm{~kg} \mathrm{~K}_{2} \mathrm{O}+400 \mathrm{~g}$ bio-fertilizer $\mathrm{K}$ with $210 \mathrm{Kg}$ mineral nitrogen or with $190 \mathrm{Kg}$ mineral $\mathrm{N}+300 \mathrm{~g}$ bio- fertilizer $\mathrm{N} /$ fad or with $34 \mathrm{~kg} \mathrm{~K} \mathrm{~K}_{2} \mathrm{O}+800 \mathrm{~g}$ bio fertilizer $\mathrm{K} /$ fed. $190 \mathrm{Kg}$ mineral $\mathrm{N}+300 \mathrm{~g}$ bio- fertilizer $\mathrm{N} /$ fed. while, the corresponding mean value in the second 
season $\left(297 \mathrm{~cm}\right.$ ) was achieved from G.T.54-9 genotype which was fertilized by $48 \mathrm{~kg} \mathrm{~K} \mathrm{~K}_{2} \mathrm{O}$ with $170 \mathrm{~kg}$ inorganic $\mathrm{N}+600 \mathrm{~g}$ bio fertilizer $\mathrm{N}$.

Table 3: Millable cane height $(\mathrm{cm})$ as affected by genotypes, bio, inorganic potassium and nitrogen fertilization rates in the plant cane and $1^{\text {st }}$ ratoon crop.

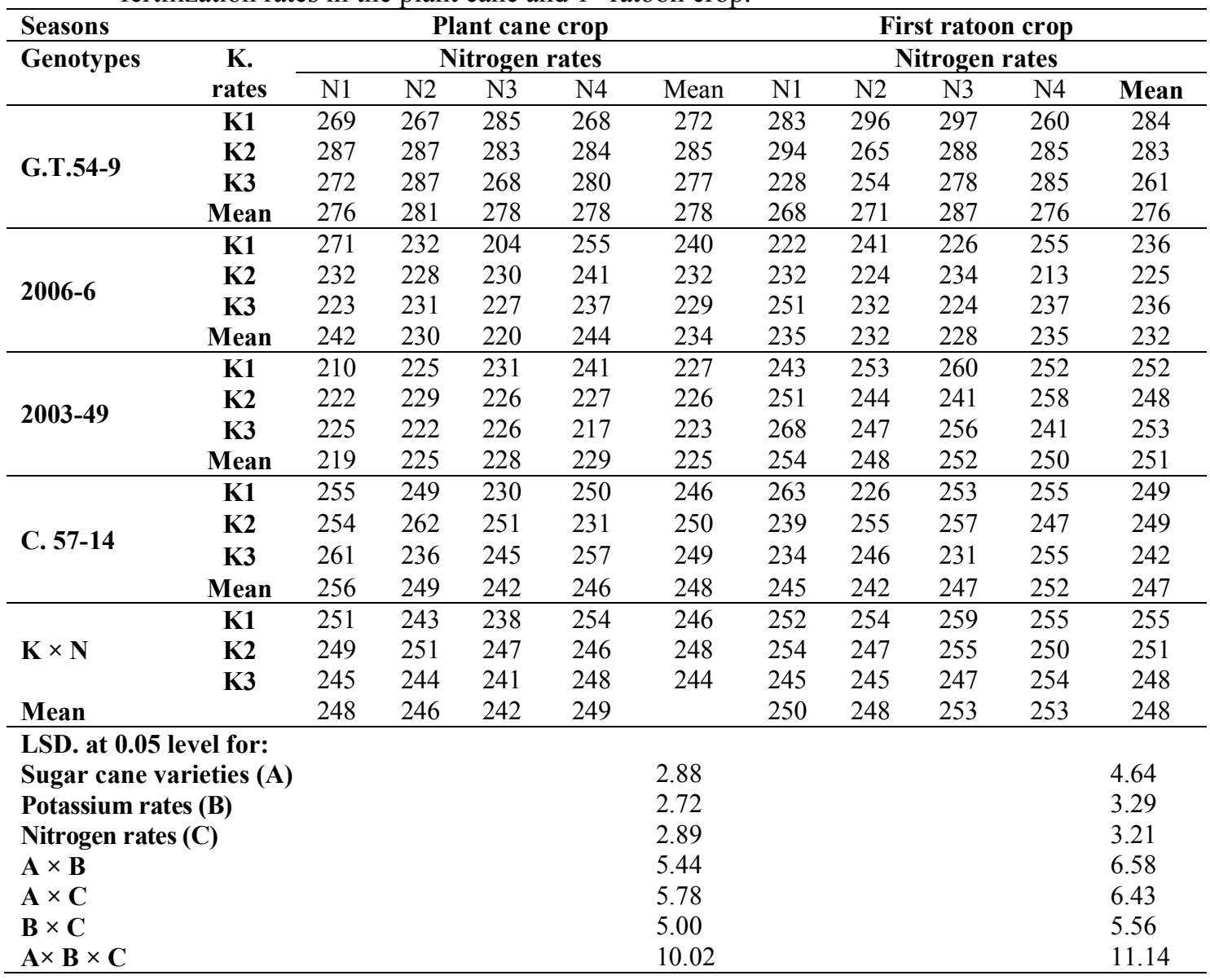

\subsection{Milable cane diameter $(\mathrm{cm})$ :}

Data in Table (4): revealed that the tested sugar cane genotypes significantly in millable cane diameter in both seasons, C. 57- 14 sugar cane genotype had the thickest millable cane, while G.2003-49 genotype had the thinnest stalks. The superiority of C. 57-14 genotype in diameter may be controlled by genetic makeup. This result coincides with that obtained by; Osman, et al (2010); Galal et. al. (2015); and Gadallah and Mehareb (2020) found that tested sugarcane varieties varied significantly in millable cane diameter in both seasons.

Also, the obtained data in Table 4 show that stalk diameter trait was significantly affected by potassium fertilization rates in plant cane only. Fertilized sugar cane plant by $34 \mathrm{~kg} \mathrm{~K}_{2} \mathrm{O}$ and $800 \mathrm{~g}$ bio fertilizerpotassium gained the thickest millable cane which was $2.73 \mathrm{~cm}$ in the first season. Similar results were obtained by Taha et al (2003); Ahmed et al. (2008) Hemeid et al. (2017) and Watanabe, et al. (2019) who reported that tested Potassium doses had significantly affected in millable cane diameter.

Furthermore, data in Table (4): focus that nitrogen fertilizer levels had a significant effect on stalk diameter in plant cane only. The highest mean value of stalk diameter (2.74) was recorded when cane plants received $170 \mathrm{Kg}$ inorganic $\mathrm{N}+600 \mathrm{~g}$ bio- N./Fed (N3). This result coincides with that obtained by Ahmed and El-Shafai (2007); Geddawy, and Makhlouf (2016) and Abazied and El-Bakry (2018) who noticed that millable cane diameter was significantly affected by $\mathrm{N}$ rates.

Here too, millable cane diameter was significantly affected by all possible interactions involved in this respect in both seasons. In addition, the maximum millable cane diameter in the first season $(3.14 \mathrm{~cm})$ was obtained from C. 57-14 sugarcane genotype which was fertilized by $40 \mathrm{~kg} \mathrm{~K}_{2} \mathrm{O}+400$ bio- $\mathrm{K}$ with 210 
$\mathrm{kg}$ inorganic $\mathrm{N}(\mathrm{K} 2 \times \mathrm{N} 1)$ while, the corresponding mean value in the second season $(3.13 \mathrm{~cm})$ was registered from the same previous genotypes which received $34 \mathrm{~kg}$ inorganic $\mathrm{K}+800 \mathrm{~g}$ bio-K with $150 \mathrm{~kg}$ inorganic $\mathrm{N}+900 \mathrm{~g}$ bio-N / fed. $(\mathrm{K} 3 \times \mathrm{N} 4)$.

Table 4: Millable cane diameter $(\mathrm{cm})$ as affected by genotypes, bio, inorganic potassium and nitrogen fertilization rates in the plant cane and $1^{\text {st }}$ ratoon crop.

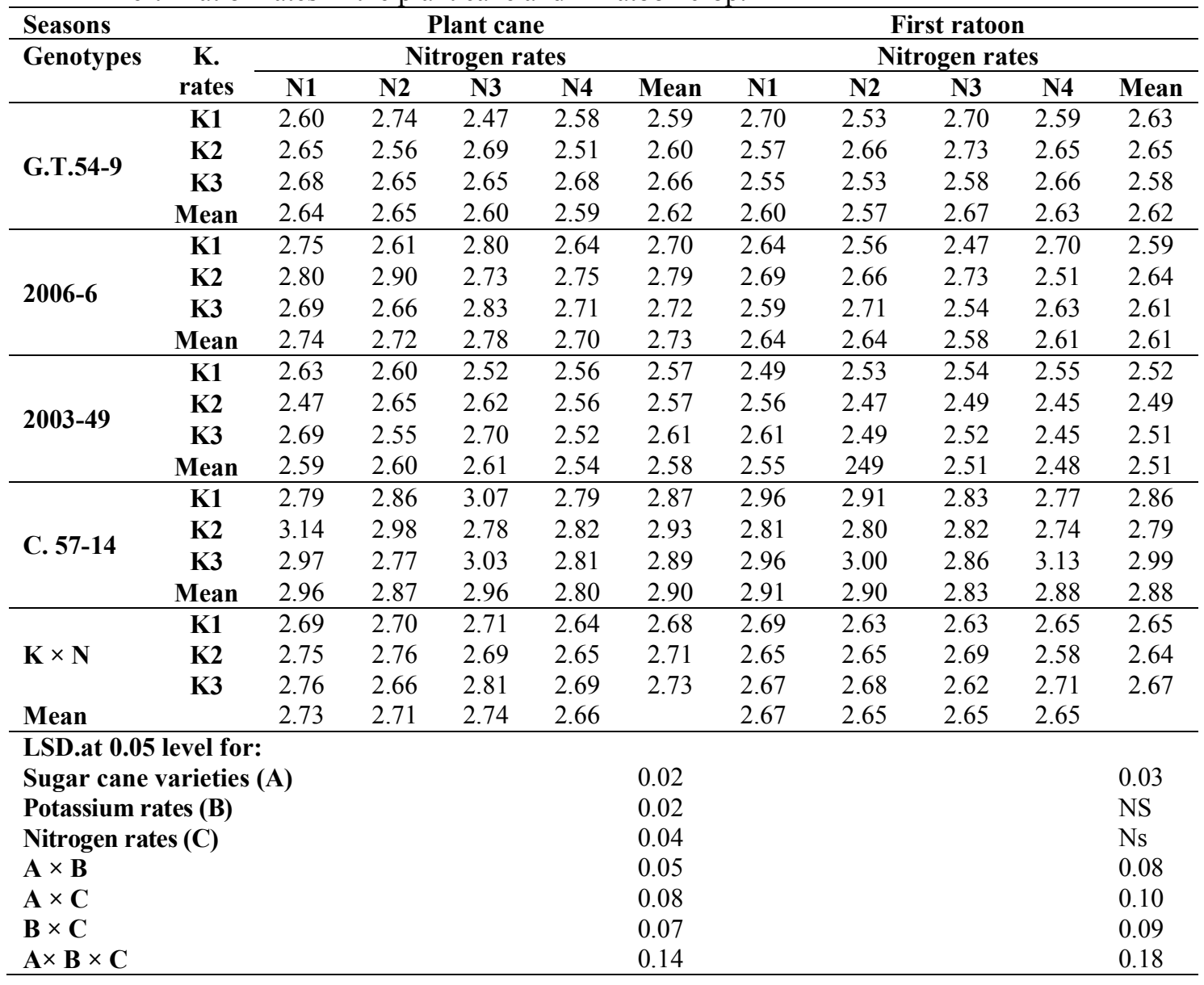

\subsection{Millable weight (kg)}

Data presented in Table (5): showed that the tested sugar cane genotypes, significantly differed in millable cane weight with the superiority of C.57-14 and G.2003-49 over the other genotypes, in plant cane crop and its first ratoon crop, respectively. The difference between the tested genotypes in this trait may be due to their gene makeup. These results are in the same line with those obtained by Galal et al. (2015); Mehareb and Abazied (2016) and Ahmed, et al. (2020) found that millable cane weight was significantly affected by the examined sugarcane varieties.

Here too, the obtained data in the same Table reveal that millable cane weight trait was significantly affected by potassium fertilization rates in plant cane only. Fertilized sugar cane plant by $40 \mathrm{~kg} \mathrm{~K}_{2} \mathrm{O}$ and 400 $\mathrm{g}$ bio-potassium gained the heaviest millable cane which was $1.104 \mathrm{~kg}$ in the first season. This increase may be due to the role of potassium fertilizer in physiological processes in plants. Watanabe, et al. (2019) and Sasy, and Abu-Ellail (2021) who reported that tested Potassium doses had significantly affected in millable cane weight.

Also, result in the same Table show that millble cane weight trait was significantly affected by $\mathrm{N}$ doses in the two seasons. However, it was noticed that $\mathrm{N} 2$ and $\mathrm{N} 3$ nitrogen treatments gave the highest mean values of millble cane weight in plant cane and first ratoon $(1.115$ and $1.141 \mathrm{~kg})$ respectively compared to the other $\mathrm{N}$ doses. These results might be due to explained through the fact that nitrogen has a vital role in building up metabolites, activating enzymes and carbohydrates accumulation which transferred from leaves to devolving stalk which in turn enhanced length, diameter and finally millable cane weight. Similar results were recorded 
by Yousif et al. (2015), Abazied and El-Bakry (2018) and Sasy, and Abu-Ellail (2021) who found that millable cane weight was significantly affected by nitrogen rates.

Table 5: Millable cane weight $(\mathrm{kg})$ as affected by genotypes, bio, inorganic potassium and nitrogen fertilization rates in the plant cane and $1^{\text {st }}$ ratoon crop.

\begin{tabular}{|c|c|c|c|c|c|c|c|c|c|c|c|}
\hline \multicolumn{2}{|l|}{ Seasons } & \multicolumn{5}{|c|}{ Plant cane } & \multicolumn{5}{|c|}{ First ratoon } \\
\hline \multirow[t]{2}{*}{ Genotypes } & \multirow{2}{*}{$\begin{array}{c}\text { K. } \\
\text { rates }\end{array}$} & \multicolumn{5}{|c|}{ Nitrogen rates } & \multicolumn{5}{|c|}{ Nitrogen rates } \\
\hline & & N1 & N2 & N3 & N4 & Mean & N1 & N2 & N3 & N4 & Mean \\
\hline \multirow{4}{*}{ G.T.54-9 } & K1 & 1.018 & 1.096 & 0.984 & 1.042 & 1.035 & 1.131 & 1.129 & 1.227 & 1.070 & 1.139 \\
\hline & K2 & 1.152 & 1.178 & 1.180 & 1.130 & 1.160 & 1.105 & 0.979 & 1.006 & 1.030 & 1.030 \\
\hline & K3 & 0.994 & 1.082 & 1.004 & 1.314 & 1.099 & 0.947 & 0.971 & 1.076 & 0.953 & 0.986 \\
\hline & Mean & 1.055 & 1.119 & 1.056 & 1.162 & 1.098 & 1.061 & 1.026 & 1.103 & 1.017 & 1.052 \\
\hline \multirow{4}{*}{ 2006-6 } & K1 & 1.166 & 1.118 & 0.984 & 1.086 & 1.089 & 0.996 & 1.000 & 0.977 & 1.071 & 1.011 \\
\hline & K2 & 0.916 & 1.002 & 1.110 & 0.984 & 1.003 & 1.214 & 1.108 & 1.096 & 1.269 & 1.172 \\
\hline & K3 & 1.044 & 1.074 & 1.014 & 0.864 & 0.999 & 1.225 & 1.128 & 1.207 & 1.179 & 1.185 \\
\hline & Mean & 1.042 & 1.065 & 1.036 & 0.978 & 1.030 & 1.145 & 1.079 & 1.093 & 1.173 & 1.123 \\
\hline \multirow{4}{*}{ 2003-49 } & K1 & 0.858 & 1.102 & 0.998 & 0.986 & 0.986 & 1.223 & 1.125 & 1.214 & 1.097 & 1.165 \\
\hline & K2 & 1.072 & 1.062 & 1.192 & 0.998 & 1.081 & 1.170 & 1.194 & 1.145 & 1.050 & 1.140 \\
\hline & K3 & 0.972 & 1.046 & 1.044 & 0.916 & 0.970 & 1.105 & 1.174 & 1.156 & 1.285 & 1.180 \\
\hline & Mean & 0.967 & 1.070 & 1.078 & 0.933 & 1.012 & 1.166 & 1.164 & 1.172 & 1.144 & 1.161 \\
\hline \multirow{4}{*}{ C. 57-14 } & K1 & 1.142 & 1.134 & 1.232 & 1.264 & 1.168 & 1.184 & 1.127 & 1.189 & 1.182 & 1.171 \\
\hline & K2 & 1.202 & 1.214 & 1.146 & 1.130 & 1.173 & 1.206 & 1.056 & 1.282 & 1.137 & 1.170 \\
\hline & K3 & 1.074 & 1.266 & 1.324 & 1.214 & 1.220 & 1.045 & 1.118 & 1.115 & 1.194 & 1.118 \\
\hline & Mean & 1.139 & 1.205 & 1.201 & 1.203 & 1.187 & 1.145 & 1.100 & 1.195 & 1.171 & 1.153 \\
\hline \multirow{3}{*}{$\mathbf{K} \times \mathbf{N}$} & K1 & 1.046 & 1.112 & 1.024 & 1.095 & 1.069 & 1.133 & 1.095 & 1.152 & 1.105 & 1.121 \\
\hline & K2 & 1.085 & 1.114 & 1.157 & 1.061 & 1.104 & 1.174 & 1.084 & 1.132 & 1.121 & 1.128 \\
\hline & K3 & 1.021 & 1.117 & 1.097 & 1.052 & 1.072 & 1.080 & 1.098 & 1.138 & 1.153 & 1.117 \\
\hline Mean & & 1.051 & 1.115 & 1.093 & 1.069 & & 1.129 & 1.092 & 1.141 & 1.126 & \\
\hline \multicolumn{12}{|c|}{ LSD.at 0.05 level for: } \\
\hline \multirow{2}{*}{\multicolumn{6}{|c|}{$\begin{array}{l}\text { Sugar cane varieties } \\
\text { Potassium rates (B) }\end{array}$}} & 0,051 & & & & & 0.025 \\
\hline & & & & & & 0.013 & & & & & NS \\
\hline \multicolumn{6}{|c|}{ Nitrogen rates $(C)$} & 0.025 & & & & & 0.025 \\
\hline \multicolumn{6}{|c|}{$\mathbf{A} \times \mathbf{B}$} & 0.027 & & & & & 0.082 \\
\hline \multicolumn{6}{|l|}{$\mathbf{A} \times \mathbf{C}$} & 0.051 & & & & & 0.051 \\
\hline \multicolumn{6}{|l|}{$\mathbf{B} \times \mathbf{C}$} & 0.044 & & & & & 0.044 \\
\hline \multicolumn{6}{|l|}{$\mathbf{A} \times \mathbf{B} \times \mathbf{C}$} & 0.089 & & & & & 0.089 \\
\hline
\end{tabular}

Concerning the interactions effect in this respect, data reveal that the first and second order interactions had a significant effect on millble cane weight in both seasons. In general, maximum weight was obtained from sugar cane C.57-14 supplying with $\mathrm{K}_{3} \times \mathrm{N}_{3}$ fertilization treatment in the first season and by $\mathrm{K}_{2} \times \mathrm{N}_{3}$ fertilization treatment in the second one.

\subsection{Cane yield ( Ton/Fad )}

The illustrated data in Table (6): denote that there were significant differences among tested sugar cane genotypes regarding cane yield/fad trait in both seasons. C.57-14 genotype produced 2.499, 3.962 and 7.175 ton/fed. higher than that obtained from G.T. 54-9, G.2006-6 and G.2003-49 genotypes respectively, in $1^{\text {st }}$ season. While, in the $2^{\text {nd }}$ season G.2003-49 genotype produced 6.748, 2.497 and 5.520 ton/fad higher than that obtained from G.T. 54-9, G.2006-6 and C.57-14 genotypes, respectively. This is to be logic since the similar trend was observed regarding number of millable cane /fed. (Table 2) in the first ratoon and stalk weight in both seasons (Table 5) as shown before. These findings are generally in line with those obtained by Osman et al. (2010); Mehareb and Abazied (2016) and Ahmed et al. (2018) they found that significant differences among the sugar cane varieties in cane yield.

Furthermore, the exhibited data in the same previous Table reveal that the cane yield trait was affected significantly by the tested bio and inorganic potassium treatments in both seasons. Applying of $40 \mathrm{Kg} \mathrm{K}_{2} \mathrm{O}$ $+400 \mathrm{~g}$ bio- $\mathrm{K} / \mathrm{fed}$. resulted in the highest cane yield in plant and ratoon cane crops. This is to be expected since the same potassium fertilization treatment gained the highest mean values of stalk weight trait as shown before (Table 5). These results are in harmony with those reported by Taha, et al. 2003; Behnam et al. 
(2015); and Hemeid et al. (2017) they noticed that cane yield was significantly affected by potassium treatments

Also, data revealed that cane yield was significantly affected by the studied bio and inorganic nitrogen levels in both seasons. The highest mean values of cane yield (49.133 and $48.913 \mathrm{Ton} / \mathrm{fed})$ in the plant cane and first ratoon, respectively, were obtained with application of $\mathrm{N} 2$ nitrogen treatment in the first season and N3 nitrogen treatment in the first ratoon. The increase in cane yield due to the application of nitrogen fertilization can be explained through the fact that nitrogen has a vital role in building up metabolites, activating enzymes and carbohydrates accumulation which transferred from leaves to devolving stalk which in turn enhanced stalk weight and cane yield per unit area. These results are in a good line with those obtained by Buragohain (2000); Rao et al. (2000); Hari and Srinivasan (2005) and El-Geddawy, and Makhlouf (2016) they found that mineral, Bio-N fertilizers, significantly affected cane yield in both seasons.

Table 6: Cane yield (Ton/fed.) as affected by genotypes, bio, inorganic potassium and nitrogen fertilization rates in the plant cane and $1^{\text {st }}$ ratoon crop.

\begin{tabular}{|c|c|c|c|c|c|c|c|c|c|c|c|}
\hline \multicolumn{2}{|l|}{ Seasons } & \multicolumn{5}{|c|}{ Plant cane } & \multicolumn{5}{|c|}{ First ratoon } \\
\hline \multirow[t]{2}{*}{ Genotypes } & \multirow{2}{*}{$\begin{array}{c}\text { K. } \\
\text { rates }\end{array}$} & \multicolumn{5}{|c|}{ Nitrogen rates } & \multicolumn{5}{|c|}{ Nitrogen rates } \\
\hline & & N1 & N2 & N3 & N4 & Mean & N1 & $\mathbf{N 2}$ & N3 & N4 & Mean \\
\hline \multirow{4}{*}{ G.T.54-9 } & K1 & 40.286 & 47.954 & 48.403 & 44.990 & 45.408 & 47.769 & 51.801 & 49.333 & 46.798 & 48.925 \\
\hline & $\mathbf{K} 2$ & 44.928 & 55.037 & 48.844 & 47.117 & 48.981 & 49.071 & 40.508 & 44.624 & 43.252 & 44.364 \\
\hline & K3 & 40.555 & 53.185 & 46.366 & 55.188 & 48.823 & 36.622 & 41.927 & 48.671 & 38.562 & 41.445 \\
\hline & Mean & 41.923 & 52.058 & 47.871 & 49.099 & 47.738 & 44.487 & 44.745 & 47.543 & 42.871 & 44.911 \\
\hline \multirow{4}{*}{ 2006-6 } & K1 & 57.273 & 47.599 & 42.467 & 49.796 & 49.284 & 43.306 & 43.126 & 41.593 & 46.267 & 43.573 \\
\hline & $\mathbf{K} 2$ & 37.638 & 44.139 & 50.261 & 44.665 & 44.176 & 52.806 & 47.200 & 49.314 & 57.820 & 51.785 \\
\hline & K3 & 46.966 & 48.313 & 48.064 & 38.114 & 45.364 & 54.378 & 49.375 & 51.409 & 53.351 & 52.128 \\
\hline & Mean & 47.292 & 46.684 & 46.931 & 44.192 & 46.275 & 50.163 & 46.567 & 47.438 & 52.479 & 49.162 \\
\hline \multirow{4}{*}{ 2003-49 } & K1 & 36.527 & 51.050 & 40.417 & 42.603 & 42.649 & 54.939 & 49.589 & 55.330 & 47.385 & 51.811 \\
\hline & K2 & 46.800 & 44.245 & 50.393 & 41.604 & 45.760 & 50.826 & 51.921 & 52.542 & 47.542 & 50.708 \\
\hline & K3 & 40.480 & 44.845 & 42.534 & 35.251 & 40.778 & 48.730 & 51.404 & 52.684 & 57.020 & 52.459 \\
\hline & Mean & 41.269 & 46.713 & 44.448 & 39.819 & 43.062 & 51.498 & 50.972 & 53.519 & 50.649 & 51.659 \\
\hline \multirow{4}{*}{ C. $57-14$} & K1 & 48.649 & 43.880 & 44.789 & 54.206 & 47.881 & 46.128 & 45.305 & 47.084 & 50.352 & 47.218 \\
\hline & K2 & 50.831 & 53.536 & 49.152 & 48.459 & 50.494 & 46.820 & 43.082 & 52.246 & 46.674 & 47.205 \\
\hline & K3 & 47.020 & 55.808 & 55.608 & 50.906 & 52.336 & 41.322 & 44.901 & 42.132 & 47.628 & 43.996 \\
\hline & Mean & 48.833 & 51.074 & 49.850 & 51.190 & 50.237 & 44.757 & 44.429 & 47.429 & 48.218 & 46.139 \\
\hline \multirow{3}{*}{$\mathbf{B} \times \mathbf{C}$} & K1 & 45.684 & 47.621 & 44.019 & 47.899 & 46.306 & 48.035 & 47.455 & 48.335 & 47.701 & 47.882 \\
\hline & K2 & 45.049 & 49.239 & 49.663 & 45.461 & 47.353 & 49.881 & 45.678 & 49.681 & 48.822 & 48.515 \\
\hline & K3 & 43.755 & 50.538 & 48.143 & 44.865 & 46.825 & 45.263 & 46.902 & 48.724 & 49.140 & 47.507 \\
\hline Mean & & 44.829 & 49.133 & 47.275 & 46.075 & & 47.726 & 46.678 & 48.913 & 48.554 & \\
\hline \multicolumn{12}{|c|}{ LSD.at 0.05 level for: } \\
\hline \multicolumn{6}{|c|}{ Sugar cane varieties (A) } & 1.356 & & & & & 0.935 \\
\hline \multicolumn{6}{|c|}{ Potassium rates (B) } & 0.535 & & & & & 0.429 \\
\hline \multicolumn{6}{|c|}{ Nitrogen rates $(\mathrm{C})$} & 0.979 & & & & & 0.698 \\
\hline \multicolumn{6}{|c|}{$\mathbf{A} \times \mathbf{B}$} & 1.071 & & & & & 2.710 \\
\hline \multicolumn{6}{|l|}{$\mathbf{A} \times \mathbf{C}$} & 1.958 & & & & & 1.398 \\
\hline \multicolumn{6}{|l|}{$\mathbf{B} \times \mathbf{C}$} & 1.696 & & & & & 1.210 \\
\hline \multicolumn{6}{|l|}{$\mathbf{A} \times \mathbf{B} \times \mathbf{C}$} & 3.392 & & & & & 2.421 \\
\hline
\end{tabular}

Also data showed that cane yield was significantly affected by the interaction between the three studied factors in the two seasons. In general, maximum cane yield /fed. (55.808 ton/fed.) was obtained from sugarcane C-57-14 supplying with $\mathrm{K}_{3} \times \mathrm{N}_{2}$ fertilization treatment in the first season. While the corresponding mean value in the second season (55.330 ton /fed.) was registered from 2003-49 sugar cane genotype fertilized with and by $\mathrm{K}_{1, \times} \mathrm{N}_{3}$ fertilization treatment in the second one.

\subsection{Nitrogen content in sugar cane leaves (\%)}

Data exhibited in Table (7) reveal that the tested sugarcane genotypes varied significantly in leaves content of $\mathrm{N}$ element in both seasons. Thus, the maximum average values of leaves $\mathrm{N}$ content (1.83 and $2.16 \%$ in the two respective seasons) were recorded from C.57-14 variety in both seasons. These results may be due to the differences among the examined varieties in their gene structure. Similar 
observations were detected by Teama et al. (2017), they noted that tested varieties differed significantly in respect to the traits of $\mathrm{N}$ leaves consists.

Here too, data in the same table showed that the studied potassium fertilization rates had a significant effect on leaves $\mathrm{N}$ content trait in the first season only. Fertilized sugar cane plants by $34 \mathrm{~kg}$ $\mathrm{K}_{2} \mathrm{O}+800 \mathrm{~g}$ bio- $\mathrm{K} /$ fed. gained the maximum mean value of $\mathrm{N}$ content in sugar cane leaves $(1.59 \%)$. It found that the effect of $\mathrm{K}$ fertilizer rates on nitrogen $\%$ in leaves of sugar cane plants was significant in plant cane only. These results are also in agreement with those reported by Hemeid et al. (2017) found that the effect of $\mathrm{K}$ fertilizer levels on nitrogen in leaves of sugar cane plants was significant.

Also, the obtained data in the same table focus that $\mathrm{N}$ content in sugar cane leaves was reacted significantly to the tested nitrogen fertilization treatments in both seasons. The highest leaves mean values consist of $\mathrm{N}$ ( 1.58 and $1.94 \%$ in the first and second seasons, respectively) were obtained from sugar cane plants which were fertilized by $170 \mathrm{~kg}$ mineral $\mathrm{N}+600 \mathrm{~g}$ bio- $\mathrm{N} / \mathrm{fed}$. in both seasons. Ashraf, et al. (2008) they found that nitrogen content in sugar cane leaves was significantly affected by nitrogen fertilization levels.

Concerning the interaction effects in this respect, data illustrated in Table 7 reveal that all the first and second order interactions involved had a significant influence on $\mathrm{N}$ content of sugar cane leaves trait in plant cane and first ratoon crops. Thus, the highest average values of $\mathrm{N}$ percentage in leaves ( 2.15 and $2.47 \%$ in the tow respective seasons) were detected by G.2006-6 genotype which was fertilized by $34 \mathrm{~kg} \mathrm{~K} 2 \mathrm{O}+800 \mathrm{~g}$ bio- $\mathrm{K} /$ fed. with $190 \mathrm{~kg}$ mineral $\mathrm{N}+300 \mathrm{~g}$ bio $-\mathrm{N} /$ fed. both seasons.

Table 7: Nitrogen percentage in leaves as affected by genotypes, bio, inorganic potassium and nitrogen fertilization rates in the plant cane and $1^{\text {st }}$ ratoon crop.

\begin{tabular}{|c|c|c|c|c|c|c|c|c|c|c|c|}
\hline \multirow{3}{*}{$\begin{array}{l}\text { Seasons } \\
\text { Genotypes }\end{array}$} & \multirow{3}{*}{$\begin{array}{c}\text { K. } \\
\text { rates }\end{array}$} & \multicolumn{5}{|c|}{ Plant cane crop } & \multicolumn{5}{|c|}{ First ratoon crop } \\
\hline & & & & ogen & & & & & ogen $r$ & & \\
\hline & & N1 & N2 & N3 & N4 & Mean & N1 & N2 & N3 & N4 & Mean \\
\hline \multirow{4}{*}{ G.T.54-9 } & K1 & 1.15 & 0.90 & 1.00 & 1.00 & 1.01 & 1.60 & 1.35 & 1.45 & 1.45 & 1.46 \\
\hline & K2 & 0.85 & 1.15 & 1.35 & 1.20 & 1.13 & 1.30 & 1.60 & 1.80 & 1.65 & 1.59 \\
\hline & K3 & 1.53 & 1.00 & 0.80 & 1.30 & 1.06 & 1.60 & 1.45 & 1.25 & 1.63 & 1.48 \\
\hline & Mean & 1.05 & 1.01 & 1.05 & 1.16 & 1.07 & 1.50 & 1.46 & 1.50 & 1.57 & 1.51 \\
\hline \multirow{4}{*}{ 2006-6 } & K1 & 1.40 & 1.80 & 1.60 & 1.85 & 1.66 & 1.72 & 2.12 & 1.92 & 2.17 & 1.98 \\
\hline & K2 & 1.80 & 1.65 & 1.90 & 1.10 & 1.61 & 2.13 & 1.97 & 2.22 & 1.42 & 1.94 \\
\hline & K3 & 2.10 & 2.15 & 2.00 & 1.65 & 1.97 & 2.43 & 2.47 & 2.33 & 1.97 & 2.30 \\
\hline & Mean & 1.76 & 1.86 & 1.83 & 1.53 & 1.75 & 2.09 & 2.19 & 2.16 & 1.86 & 2.07 \\
\hline \multirow{4}{*}{ 2003-49 } & K1 & 1.55 & 1.40 & 1.60 & 1.45 & 1.50 & 1.87 & 1.72 & 1.92 & 1.77 & 1.82 \\
\hline & K2 & 1.55 & 1.55 & 1.75 & 2.00 & 1.71 & 1.87 & 1.88 & 2.07 & 2.33 & 2.04 \\
\hline & K3 & 1.40 & 1.30 & 1.55 & 1.80 & 1.51 & 1.72 & 1.63 & 1.87 & 2.12 & 1.84 \\
\hline & Mean & 1.50 & 1.41 & 1.63 & 1.75 & 1.57 & 1.82 & 1.74 & 1.96 & 2.07 & 1.90 \\
\hline \multirow{4}{*}{ C. 57-14 } & K1 & 2.05 & 1.80 & 1.95 & 1.80 & 1.90 & 2.38 & 2.12 & 2.27 & 2.12 & 2.22 \\
\hline & K2 & 1.35 & 2.05 & 2.05 & 1.75 & 1.80 & 1.67 & 2.37 & 2.38 & 2.07 & 2.12 \\
\hline & K3 & 2.05 & 1.95 & 1.45 & 1.80 & 1.81 & 2.37 & 2.37 & 1.77 & 2.12 & 2.13 \\
\hline & Mean & 1.81 & 1.93 & 1.81 & 1.78 & 1.83 & 2.14 & 2.26 & 2.14 & 2.11 & 2.16 \\
\hline \multirow{3}{*}{$\mathbf{A} \times \mathbf{B}$} & K1 & 1.53 & 1.47 & 1.53 & 1.52 & 1.51 & 1.89 & 1.83 & 1.89 & 1.88 & 1.87 \\
\hline & K2 & 1.38 & 1.60 & 1.76 & 1.51 & 1.56 & 1.74 & 1.95 & 2.12 & 1.87 & 1.92 \\
\hline & K3 & 1.67 & 1.60 & 1.45 & 1.63 & 1.59 & 2.03 & 1.95 & 1.80 & 1.96 & 1.94 \\
\hline Mean & & 1.53 & 1.55 & 1.58 & 1.55 & & 1.89 & 1.91 & 1.94 & 1.90 & \\
\hline \multicolumn{12}{|c|}{ LSD.at 0.05 level for: } \\
\hline \multicolumn{6}{|c|}{ Sugar cane varieties (A) } & 0.01 & & & & & 0.03 \\
\hline \multicolumn{6}{|c|}{ Potassium rates $(\mathrm{B})$} & 0.01 & & & & & NS \\
\hline \multicolumn{6}{|c|}{ Nitrogen rates (C) } & 0.01 & & & & & 0.02 \\
\hline \multicolumn{6}{|c|}{$\mathbf{A} \times \mathbf{B}$} & 0.02 & & & & & 0.04 \\
\hline \multicolumn{6}{|l|}{$\mathbf{A} \times \mathbf{C}$} & 0.03 & & & & & 0.03 \\
\hline \multicolumn{6}{|l|}{$\mathbf{B} \times \mathbf{C}$} & 0.02 & & & & & 0.03 \\
\hline \multicolumn{6}{|l|}{$\mathbf{A} \times \mathbf{B} \times \mathbf{C}$} & 0.05 & & & & & 0.05 \\
\hline
\end{tabular}

\subsection{Potassium content in sugar cane leaves (\%)}

Data exhibited in Table 9 reveal that the tested sugar cane genotypes varied significantly in leaves content of $\mathrm{K}$ element in both seasons. Thus, the maximum average values of leaves $\mathrm{K}$ content (1.51 and 
$1.13 \%$ in the two respective seasons) were recorded from C.57-14 and G.2006-6 genotypes, respectively. These results may be due to the differences among the examined varieties in their gene structure. Similar observations were detected by Teama et al. (2017) they found that varieties differed significantly in respect to the traits of potassium leaves consists.

Here too, data in the same table show that the studied potassium fertilization rates had a significant effect on leaves $\mathrm{K}$ content trait in both seasons. Fertilized sugar cane plants by $34 \mathrm{~kg} \mathrm{~K}_{2} \mathrm{O}+$ $800 \mathrm{~g}$ bio- $\mathrm{K} / \mathrm{fed}$. gained the maximum mean value of $\mathrm{K}$ content in sugar cane leaves $(0.98 \%)$ in the first season while, Fertilized sugar cane plants by $48 \mathrm{~kg} \mathrm{~K}_{2} \mathrm{O}$ /fed. gained the maximum mean value of $\mathrm{K}$ content in sugarcane leaves (1.05\%) in the first season. Hemeid et al. (2017) They reported that the effect of $\mathrm{K}$ fertilizer levels on potassium $\%$ in leaves of sugar cane plants was significant in plant cane and $1^{\text {st }}$ ratoon.

Also, the obtained data in the same table focus that $\mathrm{K}$ content in sugar cane leaves was reacted significantly to the tested nitrogen fertilization treatments in both seasons.

The highest leaves mean values consist of K $(0.99$ and $1.04 \%$ in the first and second seasons, respectively) were obtained from sugar cane plants which were fertilized by $170 \mathrm{~kg}$ mineral $\mathrm{N}+600 \mathrm{~g}$ bio- N/fed. in both seasons. Ashraf, et al. (2008) they found that K content in sugar cane leaves was significantly affected by nitrogen fertilization levels.

Concerning the interaction effects in this respect, data reveal that all the first and second order interactions involved had a significant influence on $\mathrm{K}$ content of sugar cane leaves in both seasons. Thus, the highest average value of $\mathrm{K}$ percentage in leaves (1.32 in the first season) was detected by G.2006-6 genotype which was fertilized by $34 \mathrm{~kg} \mathrm{~K}_{2} \mathrm{O}+800 \mathrm{~g}$ bio- $\mathrm{K} / \mathrm{fed}$. with $190 \mathrm{~kg}$ mineral $\mathrm{N}+$ $300 \mathrm{~g}$ bio $-\mathrm{N} / \mathrm{fed}$. while, the corresponding mean value in the second season (1.34\%) was detected by G.2006-6 genotype which was fertilized by $48 \mathrm{~kg} \mathrm{~K}_{2} \mathrm{O}$ with $170 \mathrm{~kg}$ mineral $\mathrm{N}+600 \mathrm{~g}$ bio $-\mathrm{N} / \mathrm{fed}$.

Table 10: Potassium percentage in leaves as affected by genotypes, bio, inorganic potassium and nitrogen fertilization rates in the plant cane and $1^{\text {st }}$ ratoon crop.

\begin{tabular}{|c|c|c|c|c|c|c|c|c|c|c|c|}
\hline \multirow{3}{*}{\begin{tabular}{|l|} 
Seasons \\
Genotypes
\end{tabular}} & \multirow{3}{*}{$\begin{array}{c}\text { K. } \\
\text { rates }\end{array}$} & \multicolumn{5}{|c|}{ Plant cane crop } & \multicolumn{5}{|c|}{ First ratoon crop } \\
\hline & & & & ogen & & & & & ogen & & \\
\hline & & N1 & N2 & N3 & N4 & Mean & N1 & N2 & N3 & N4 & Mean \\
\hline \multirow{4}{*}{ G.T.54-9 } & K1 & 0.87 & 0.96 & 0.85 & 0.76 & 0.86 & 0.98 & 1.03 & 0.97 & 0.92 & 0.97 \\
\hline & K2 & 0.78 & 0.80 & 0.82 & 0.78 & 0.79 & 0.93 & 0.92 & 0.93 & 0.91 & 0.92 \\
\hline & K3 & 0.46 & 0.78 & 0.84 & 0.51 & 0.65 & 0.72 & 0.93 & 0.97 & 0.78 & 0.85 \\
\hline & Mean & 0.70 & 0.84 & 0.84 & 0.68 & 0.77 & 0.88 & 0.96 & 0.95 & 0.87 & 0.91 \\
\hline \multirow{4}{*}{ 2006-6 } & K1 & 1.13 & 1.05 & 1.02 & 1.02 & 1.06 & 1.09 & 1.05 & 1.34 & 1.34 & 1.20 \\
\hline & K2 & 1.07 & 1.14 & 1.13 & 1.18 & 1.13 & 1.06 & 1.09 & 1.09 & 1.11 & 1.08 \\
\hline & K3 & 1.09 & 1.32 & 1.18 & 1.05 & 1.16 & 1.07 & 1.17 & 1.10 & 1.04 & 1.09 \\
\hline & Mean & 1.10 & 1.17 & 1.11 & 1.08 & 1.11 & 1.07 & 1.10 & 1.17 & 1.16 & 1.13 \\
\hline \multirow{4}{*}{ 2003-49 } & K1 & 0.78 & 0.76 & 0.71 & 0.71 & 0.74 & 0.94 & 0.93 & 0.90 & 0.90 & 0.91 \\
\hline & K2 & 0.73 & 0.76 & 0.69 & 0.93 & 0.78 & 0.91 & 0.92 & 0.89 & 0.99 & 0.93 \\
\hline & $\mathbf{K 3}$ & 0.87 & 1.00 & 1.02 & 1.00 & 0.97 & 0.98 & 1.02 & 1.03 & 1.02 & 1.01 \\
\hline & Mean & 0.79 & 0.84 & 0.81 & 0.88 & 0.83 & 0.94 & 0.96 & 0.94 & 0.97 & 0.95 \\
\hline \multirow{4}{*}{ C. $57-14$} & K1 & 1.25 & 1.14 & 1.20 & 1.14 & 1.18 & 1.14 & 1.09 & 1.11 & 1.09 & 1.11 \\
\hline & K2 & 1.18 & 1.04 & 1.18 & 1.13 & 1.13 & 1.10 & 1.05 & 1.11 & 1.09 & 1.08 \\
\hline & K3 & 1.09 & 0.98 & 1.20 & 1.25 & 1.13 & 1.06 & 1.01 & 1.11 & 1.14 & 1.08 \\
\hline & Mean & 1.17 & 1.05 & 1.19 & 1.17 & 1.51 & 1.10 & 1.05 & 1.11 & 1.10 & 1.09 \\
\hline \multirow{3}{*}{$\mathbf{A} \times \mathbf{B}$} & K1 & 1.01 & 0.97 & 0.94 & 0.91 & 0.96 & 1.03 & 1.02 & 1.08 & 1.06 & 1.05 \\
\hline & K2 & 0.94 & 0.93 & 0.95 & 1.00 & 0.96 & 1.00 & 0.99 & 1.00 & 1.02 & 1.00 \\
\hline & K3 & 0.88 & 1.02 & 1.06 & 0.95 & 0.98 & 0.96 & 1.03 & 1.05 & 0.99 & 1.01 \\
\hline Mean & & 0.94 & 0.97 & 0.99 & 0.95 & & 1.00 & 1.02 & 1.04 & 1.02 & \\
\hline \multicolumn{12}{|c|}{ LSD. at 0.05 level for: } \\
\hline \multicolumn{6}{|c|}{ Sugar cane varieties (A) } & 0.01 & & & & & 0.02 \\
\hline \multicolumn{6}{|c|}{ Potassium rates (B) } & 0.01 & & & & & 0.01 \\
\hline \multicolumn{6}{|c|}{ Nitrogen rates $(C)$} & 0.01 & & & & & 0.01 \\
\hline \multicolumn{6}{|c|}{$\mathbf{A} \times \mathbf{B}$} & 0.02 & & & & & 0.03 \\
\hline \multicolumn{6}{|l|}{$\mathbf{A} \times \mathbf{C}$} & 0.03 & & & & & 0.03 \\
\hline \multicolumn{6}{|l|}{$\mathbf{B} \times \mathbf{C}$} & 0.02 & & & & & 0.02 \\
\hline \multicolumn{6}{|l|}{$\mathbf{A} \times \mathbf{B} \times \mathbf{C}$} & 0.05 & & & & & 0.05 \\
\hline
\end{tabular}




\subsection{Soil fertility}

Data in Table 11 showed that Inoculated plants of sugarcane at sowing with bio-NK fertilizer had positive effect on soil fertility, where it increased soil content of available nitrogen and potassium that increasing the application rate of mineral NK fertilizer significantly enhanced soil content of available $\mathrm{N}$ and $\mathrm{K}$ as compared with soil before planting sugarcane. Significant differences were observed between the four sugarcane genotypes in soil content of available $\mathrm{N}$ and $\mathrm{K}$. The maximum average values of available $\mathrm{N}$ and $\mathrm{K}$ in soil after planting (60.36 and $248 \mathrm{mg} \mathrm{kg}-1)$ were recorded from C.57-14 genotypes in the two seasons.

Table 11: Availability of nitrogen and potassium contents in soils $\left(\mathrm{mg} \mathrm{kg}^{-1}\right)$ at harvest date as affected by genotypes, bio, inorganic potassium and nitrogen fertilization rates (combined date of plant cane and $1^{\text {st }}$ ratoon crops

\begin{tabular}{|c|c|c|c|c|c|c|c|c|c|c|c|}
\hline \multirow{3}{*}{$\begin{array}{l}\text { Seasons } \\
\text { Genotypes }\end{array}$} & \multirow{3}{*}{$\begin{array}{c}\text { K. } \\
\text { rates }\end{array}$} & \multicolumn{5}{|c|}{ Available $N$ in soil (mg kg-1) } & \multicolumn{5}{|c|}{ Available K in soil (mg kg-1) } \\
\hline & & & & $\operatorname{cogen} r$ & & & & & ggen 1 & & \\
\hline & & N1 & N2 & N3 & N4 & Mean & N1 & N2 & N3 & N4 & Mean \\
\hline \multirow{4}{*}{ G.T.54-9 } & K1 & 48.33 & 40.66 & 44.00 & 43.66 & 44.16 & 226 & 236 & 224 & 213 & 225 \\
\hline & K2 & 39.00 & 48.00 & 54.00 & 50.00 & 47.75 & 216 & 212 & 214 & 209 & 213 \\
\hline & K3 & 48.33 & 43.66 & 37.66 & 49.00 & 44.66 & 167 & 216 & 224 & 179 & 196 \\
\hline & Mean & 45.22 & 44.11 & 45.22 & 47.55 & 45.52 & 203 & 221 & 221 & 200 & 211 \\
\hline \multirow{4}{*}{ 2006-6 } & K1 & 52.00 & 53.33 & 56.00 & 55.00 & 54.08 & 251 & 241 & 244 & 239 & 244 \\
\hline & K2 & 54.33 & 51.00 & 54.33 & 42.66 & 50.58 & 243 & 251 & 250 & 255 & 250 \\
\hline & K3 & 57.33 & 57.66 & 57.66 & 59.33 & 58.00 & 245 & 246 & 255 & 241 & 247 \\
\hline & Mean & 54.55 & 54.00 & 56.00 & 52.33 & 45.22 & 246 & 246 & 250 & 245 & 247 \\
\hline \multirow{4}{*}{ 2003-49 } & K1 & 56.00 & 53.00 & 58.00 & 53.00 & 55.00 & 227 & 224 & 223 & 226 & 225 \\
\hline & K2 & 56.33 & 56.33 & 62.33 & 61.00 & 59.00 & 223 & 218 & 204 & 229 & 218 \\
\hline & K3 & 51.66 & 48.66 & 56.33 & 60.66 & 54.33 & 226 & 235 & 239 & 236 & 234 \\
\hline & Mean & 54.66 & 52.66 & 58.88 & 58.22 & 56.11 & 225 & 226 & 222 & 230 & 226 \\
\hline \multirow{4}{*}{ C. 57-14 } & K1 & 61.33 & 62.66 & 60.66 & 64.00 & 62.16 & 262 & 251 & 257 & 251 & 255 \\
\hline & K2 & 50.33 & 61.33 & 62.00 & 62.00 & 58.91 & 255 & 241 & 245 & 250 & 248 \\
\hline & K3 & 62.00 & 60.66 & 53.33 & 64.00 & 60.00 & 245 & 233 & 252 & 239 & 242 \\
\hline & Mean & 57.88 & 61.55 & 58.66 & 63.33 & 60.36 & 254 & 241 & 251 & 247 & 248 \\
\hline \multirow{3}{*}{$\mathbf{A} \times \mathbf{B}$} & K1 & 54.41 & 52.41 & 54.66 & 53.91 & 53.85 & 241 & 238 & 237 & 232 & 237 \\
\hline & K2 & 50.00 & 54.16 & 58.16 & 53.91 & 54.06 & 234 & 230 & 228 & 236 & 232 \\
\hline & K3 & 54.83 & 52.66 & 51.25 & 58.25 & 54.25 & 221 & 232 & 242 & 224 & 230 \\
\hline Mean & & 53.08 & 53.08 & 54.69 & 55.36 & & 232 & 233 & 236 & 230 & \\
\hline \multicolumn{11}{|c|}{ LSD. at 0.05 level for: } & 1.55 \\
\hline \multicolumn{6}{|c|}{ Potassium rates (B) } & n.s & & & & & 1.76 \\
\hline \multicolumn{6}{|c|}{ Nitrogen rates (C) } & 1.08 & & & & & 3.53 \\
\hline \multicolumn{6}{|c|}{$\mathbf{A} \times \mathbf{B}$} & 0.50 & & & & & 1.39 \\
\hline \multicolumn{6}{|l|}{$\mathbf{A} \times \mathbf{C}$} & 0.75 & & & & & 2.09 \\
\hline \multicolumn{6}{|l|}{$\mathbf{B} \times \mathbf{C}$} & 0.87 & & & & & 2.42 \\
\hline \multicolumn{6}{|l|}{$\mathbf{A} \times \mathbf{B} \times \mathbf{C}$} & 1.74 & & & & & 4.84 \\
\hline
\end{tabular}

At the time of sowing $\mathrm{N}$ level in soil was $40 \mathrm{mg} \mathrm{kg}^{-1}$ and $\mathrm{K}$ level was $210 \mathrm{mg} \mathrm{kg}^{-1}$. While, NK levels in soil at time of harvesting were 54 and $233 \mathrm{mg} \mathrm{kg}^{-1}$. Fertilized sugar cane plants by $34 \mathrm{~kg}$ mineral $\mathrm{K}_{2} \mathrm{O}+800 \mathrm{~g}$ bio- $\mathrm{K} / \mathrm{fed}$. gained the maximum mean value of available $\mathrm{N}$ in soil at time of harvesting $\left(54.25 \mathrm{mg} \mathrm{kg}^{-1}\right)$.while, Fertilized sugar cane plants by $48 \mathrm{~kg}$ mineral $\mathrm{K}_{2} \mathrm{O} / \mathrm{fed}$. gained the maximum mean value of available $\mathrm{K}$ in soil at time of harvesting $\left(237 \mathrm{mg} \mathrm{kg}^{-1}\right)$.

Here too, data in the same table show that the studied nitrogen fertilization rates had a significant effect on available $\mathrm{N}$ and $\mathrm{K}$ in soil at time of harvesting. Fertilized sugar cane plants by N4: $150 \mathrm{~kg}$ inorganic nitrogen $+900 \mathrm{~g}$ bio fertilizer/ fed. gained the maximum mean value of available $\mathrm{N}$ in soil at time of harvesting $\left(55.36 \mathrm{mg} \mathrm{kg}^{-1}\right)$. While, fertilized sugar cane plants by $\mathrm{N} 3: 170 \mathrm{~kg}$ nitrogen $+600 \mathrm{~g}$ bio fertilizer gained the maximum mean value of available $\mathrm{K}$ in soil at time of harvesting $(236 \mathrm{mg} \mathrm{kg}$ $\left.{ }^{1}\right)$.

Concerning the interaction effects in this respect, data reveal that combined data of 2018/2019 and 2019/2020 seasons order interactions involved had on available $\mathrm{N}$ and $\mathrm{K}$ in soil at time of 
harvesting. Thus, the highest average value of available $\mathrm{N}$ in soil at time of harvesting was detected by C. 57-14 genotype which was fertilized by $48 \mathrm{~kg} \mathrm{~K}_{2} \mathrm{O}$ and $34 \mathrm{~kg} \mathrm{~K}_{2} \mathrm{O}+800 \mathrm{~g}$ bio- fertilizer /fed. with (N4) $150 \mathrm{~kg}$ inorganic nitrogen $+900 \mathrm{~g}$ bio fertilizer/ fed. $\left(64 \mathrm{mg} \mathrm{kg}^{-1}\right)$. While, highest average value of available $\mathrm{K}$ in soil at time of harvesting was detected by C. 57-14 genotype which was fertilized by 48 $\mathrm{kg} \mathrm{K} 2 \mathrm{O} /$ fed. with (N1) $210 \mathrm{~kg}$ nitrogen / fed. $\left(262 \mathrm{mg} \mathrm{kg}^{-1}\right)$. NK + Bio fertilizers improved the NK status of the soil due to $\mathrm{N}$ fixation by Azotobacter and Azospirillum. Thus, improved the potassium soluble bacteria (KSB) solubilize the unavailable form of potassium into available form. Bio fertilization had moderately enhanced the fertility level of the soil after sugarcane harvest. These results are also in agreement with those reported by Stamford et al.(2008) evaluated the effectiveness of a bio fertilizer on sugarcane yield and its effects on some chemical attributes of a soil with low $\mathrm{N}$ and $\mathrm{K}$ availability, and considered that bio fertilizers are a potential source for use in sugarcane. A combination of inorganic and bio fertilizers is a potential tool for sustaining the cane productivity as well as soil fertility in sugarcane. Jha et al. (2019) found that Integration of chemical fertilizer with bio fertilizers was more effective for sustainable sugarcane production and maintenance of soil health.

\section{Conclusion}

Under conditions of the present work, supplying sugar cane G.2006-6 genotypes with $100 \%$ of the recommended inorganic k-rate $\left(48 \mathrm{~kg} \mathrm{~K}_{2} \mathrm{O} / \mathrm{fed}\right)$ integrated with $100 \%$ of the recommended inorganic N-rate $(210 \mathrm{~kg} / \mathrm{fed})$ and $90 \%$ of the recommended inorganic K-rate $(40 \mathrm{~kg})+400 \mathrm{~g}$ bio- K /fed. integrated with $70 \%$ of recommended inorganic N-rate $(150 \mathrm{~kg})+900 \mathrm{~g}$ bio- $\mathrm{N} /$ fad resulted in the highest cane yield/fad in plant cane and its first ratoon crops, respectively.

\section{References}

A.O.A.C., 1990. Official Methods of Analysis of the Association of Official Analytical Chemists. 15th (edition, published by Association of Official Analytical Chemists Arlington, Virginia U.S.A.).

Abazied, Sakina, R. and A. El-Bakry, 2018. Effect of excessive nitrogen fertilization on yield and juice quality of some sugar cane varieties. J. Biol. Chem. Environ. Sci., 13 (2): 135-158.

Ahamed, A.Z., E.H.S. El-Laboudy and Sherin, H.A. Al-Maracy, 2020. Productivity and quality of some sugar cane varieties as influenced by seeding rate. J. Biol., Chem. Environ., Sci., 15 (2): 31-47.

Ahmed, A.Z., A.B.A. El-Taib and A.K. Eanar, 2018. Evaluation of sugar cane genotypes under different row spacing. Egyptian Sugar J., 11: 145- 156.

Ahmed, Z.A. and A.M.A. El-Shafai, 2007. Yield and quality of two sugar cane varieties as affected by bio and inorganic nitrogen fertilization. J. Agric. Sci. Mansoura Univ, 32 (1): 61-76 .

Ahmed, Z.A., K.S. El-Sogheir and A.M.A. Ismail, 2008. Response of three sugar cane varieties to different levels of potassium and phosphorus fertilization. Egypt J. Appl. Sci., 23 (4-A): 153-167.

Ashraf, M.Y., F. Hussain, J. A khter, A. Gul, M. Ross and G. Ebert, 2008. Effect of different sources and rates of nitrogen and supra optimal level of potassium fertilization on growth, yield and nutrient uptake by sugarcane grown under saline conditions. Pak. J. Bot., (4): 1521-1531.

Behnam, H., P. Ebrahim and G. Ali, 2015. Effects of Potassium sulfate fertilizer application on sugar cane (Cultivar CP 48-103) qualitative-quantitative Yield. J. Res. Crop Ecophysiology, Iran, 10/2 (1): $33-40$.

Black, C.A., 1965. Method of Soil Analysis" Am. Soc. of Agronomy. Inc., Publisher Madison, Wiscconsin, USA.

Buragohain, S.K., 2000. Efficacy of biofertilizers with varying levels of $\mathrm{N}$ on growth, yield and quality of sugarcane (Saccharum officinarum L.). Indian Sugar, 49 (10): 847-850.

El-Geddawy, I.H. Dalia and B.S.I. Makhlouf, 2016. Effect of using N- fixation organism (Azotobacter) on nitrogen fertilizer requirements for some sugar cane varieties. Proc., $14^{\text {th }}$ Inter. Conf. Suez Canal Univ. Egypt, 340-361.

Gadallah A.F.I. and E.M. Mehareb, 2020. Yield and quality of some sugar cane varieties as affected by irrigation number. Nter. J. Agric. Sci. 2 (2): 144-165.

Galal, M.O.A., A.M. Abou-salama, E.A. Teama and A.Z. Ahmed, 2015.Yield Response of Late Planted Spring Sugar cane to Direct Set Sowing and Transplanting. J. King Faisal, Univ. 16 (1): 75-94. 
Hari. K. and T.R. Srinivasan, 2005. Response of sugarcane varieties to application of nitrogen fixing bacteria under different nitrogen levels .Sugar Tech., 7 (2\&3): 28-31.

Hemeid, Nadia M., Basma R.A. Rashwan, E.I. Mohamed and F.A. Khalil, 2017. Impact of potassium fertilization and cultivation methods on productivity and water use efficiency of Sugarcane. J. Soil Sci. Agric. Eng., Mansoura Univ., 8 (5):195 -202.

Jha, C.K., S.K. Sinha, S.K. Thakur and V. Kumar, 2019. Soil properties, productivity and juice quality of sugarcane through integration of organic and inorganic nutrient sources in calcareous soil. international Journal of Chemical Studies, SP6: 297-302

Mehareb, E.M. and Sakena R. Abazied, 2016. Broad sense heritability and genetic variance of some promising sugar cane varieties under harvesting ages for juice quality traits, cane and sugar yield. Egypt. J. Plant Breed, 20 (6):1135- 1153.

Osman, A.M.H., A.M. Abd El-Razek and M.S.H. Osman, 2010. Yield and quality of three sugar cane varieties as affected by No. of ploughing. Egypt. J. Appl. Sci., 25 (7): 324-332.

Rao-V.V., P.R. Babu and J.V.R.B. Rao, 2000. Effect of Azospirillum and Azetobacter with different levels of inorganic nitrogen on cane yield and juice quality of sugar cane. Proc. $62^{\text {nd }}$ Ann-Conv., Sugar-Tec.'-Associ. Agra,-India, 122-130.

Ryan, J., S. Garabet, K. Harmsen, and A.A. Rashid, 1996. Soil and Plant Analysis Manual Adapted for the west Asia and North Africa Region. ICARDA, Aleppo, Syria. 140.

Sasy, A.H. and F.F.B. Abu-Ellail, 2021. Phenotypic correlations and integration of nitrogen, potassium and press mud fertilizers in relation to sugar cane yield and quality. Alex., Sci., Exch., J., 42 (1): 38-48.

Snedecor, G.W. and W.G. Cochran, 1981. Statistical Methods. Seventh Ed., Iowa State Univ. Press, Ames, Iowa, USA.

Stamford, N.R, R.A. Lima, J.R.M.A. Lira, and C.R.S. Santos, 2008. Effectiveness of phosphate and potash rocks with Acidithiobacilluson sugarcane yield and their effects on soil chemical attributes. World Journal of Microbiology and Biotechnology, 24(10):2061-2066

Steel, R.G.D. and J.H. Torrie, 1980. Principles and procedures of statistics. Mc Grow-Hill Book Co. Inc., New York.

Taha, E.M., A.Z. Ahmed and K.S. El-Soghier, 2003. Response of four sugar cane varieties to potassium fertilizer. Egypt. J. Agric., 81 (1):151-161.

Teama, E.A., A.M. Abou-Salama, I.H. EL-Geddawy M.T. Said and M.F.A. Moustafa, 2017. Chemical Properties and Juice Quality of Three Sugar cane Varieties as Affected by Gypsum, Filter Mud Cake and Inorganic Fertilization. Assiut J. Agric. Sci., 48 (4):44-63.

Watanabe, K., C. Ngasan, S. Saensupo and K. Sriroth, 2019. Studies into Potassium Management for Sugar cane Production in Northeast Thailand Based on Factory Juice Analysis Combined with Cultivation Experiment. American J. Agric. \& Fores, 7 (6):239-247.

Yousif, E.M.M., M.M. IbrahIm, A.O.A.O. El-Aref Kh. and A.Z. Ahamed, 2015. Management of nitrogen fertilization for sugar cane on a sandy Soil: I yield and its components, Egypt. J. Appl. Sci., 30 (11):498-511. 